\title{
Comportamiento a cortante en vigas de concreto reforzado con deterioro por corrosión en los estribos
}

\section{Shear strength behaviour on corrosion damaged stirrups of reinforced concrete beams}

\author{
Bianca Guevara*1, César Juárez*, Gerardo Fajardo*, Pedro Castro-Borges**
}

\author{
* Universidad Autónoma de Nuevo León UANL, MÉXICO \\ **CINVESTAV-IPN Unidad Mérida, Yucatán. MÉXICO
}

Resumen

Contribución. Mejor artículo Contribution. Best paper award Conpat 2009 PAG. 259 - 270

Esta investigación propone realizar estudios en vigas de concreto reforzado, en las que se induzca un deterioro controlado por corrosión en el refuerzo transversal encontrando correlaciones entre diferentes grados de corrosión en los estribos y la resistencia por cortante debido a la tensión diagonal. Se fabricaron 2 series de 8 vigas con una separación de 150 y $200 \mathrm{~mm}$ entre estribos para cada serie. Las vigas están siendo expuestas a ciclos de humectación utilizando una solución de $3.5 \%$ de $\mathrm{NaCl}$ y secado al aire libre. Aquí se discuten resultados preliminares asociados al seguimiento del potencial de corrosión de los estribos antes y durante la exposición de las vigas al cloruro de sodio. Los resultados obtenidos permitirán conocer el efecto del grado de deterioro de los estribos sobre el comportamiento por cortante en las vigas, y el correspondiente patrón de agrietamiento.

Palabras Clave: Corrosión, cortante, tensión diagonal, cloruros, refuerzo transversal

Abstract

The present research intends to develop studies on reinforced concrete beams by applying controlled damage corrosion to cross-sectional reinforcements, thus finding relationships between different stirrups corrosion levels and shear strength due to diagonal tensile stress. Two series of eight beam specimens were constructed, each series having a stirrup spacing distance of 150 and $200 \mathrm{~mm}$. The beams are exposed under wetting/drying cycles, with a $3.5 \% \mathrm{NaCl}$ solution. In this paper, preliminary results are discussed related to the control of stirrups corrosion potential while the beams are exposed to $\mathrm{NaCl}$. The obtained results will allow understanding the effect of stirrups corrosion level upon beams shear strength behavior, and the corresponding cracking pattern

Keywords: Corrosion, shear strength, diagonal tensile stress, chloride, cross-sectional reinforcement

\section{Introducción}

Históricamente, el diseño de las estructuras de concreto se ha realizado con el criterio de la resistencia mecánica; con esta base se ha logrado tener estructuras que soportan adecuadamente las cargas de servicio; sin embargo, se han incrementado los problemas relacionados con el medio ambiente en el que se encuentra la estructura (Hernández y Mendoza, 2006). En los últimos años, ha crecido el número de estructuras de concreto reforzado con problemas de corrosión en el refuerzo y ha resultado ser un problema serio en puentes,

\section{Introduction}

Historically, the design of concrete structures has been developed fulfil mechanical strength criteria; obtaining structures which bearing capacity well appropriate for service load. However, there are an increasing number of environmental problems, depending on the place where the structure is exposed. (Hernández and Mendoza, 2006). During recent years, the number of reinforced concrete structures showing corrosion damage has become a serious problem for structures such as bridges,

\footnotetext{
1 Autor de correspondencia / Corresponding author:

E-mail: biancaguevara@live.com.mx
} 
estructuras para estacionamientos y otras estructuras de carreteras en las cuales su principal característica es que se encuentran expuestas a la intemperie, también en estructuras expuestas a un ambiente marino y en plantas productoras de sustancias químicas. Debido a esto, la corrosión en el sistema acero-concreto, es un fenómeno que desde hace décadas despertó el interés de muchos investigadores a nivel mundial, esto debido a la importancia del concreto reforzado como el sistema de construcción más utilizado en el mundo (Park y Paulay, 1990). La corrosión del acero de refuerzo, representa en forma integral el problema de durabilidad que más afecta a las estructuras de concreto reforzado. Siendo entonces uno de los deterioros que mayor costo induce en el mantenimiento y operación de las diversas construcciones que se realizan con este material (Helene y Pereira, 2003).

En 1990 se realizó un estudio internacional del impacto que produce el costo económico originado por la corrosión en estructuras de concreto reforzado, el resultado fue que entre el 2 y el $5 \%$ del Producto Nacional Bruto (PNB) de cada país se destina a subsanar los problemas de corrosión; pero entre un 15 y $25 \%$ se pudo haber evitado si se hubiese aplicado la tecnología existente para contrarrestarla. En el Reino Unido, un país desarrollado destina $40 \%$ de la inversión en construcción a la reparación y al mantenimiento, $4 \%$ de su Producto Interno Bruto (Hernández y Mendoza, 2006). Por otra parte, en los Estados Unidos existen aproximadamente 235,000 puentes convencionales de concreto reforzado en servicio; de los cuales 21,000 están estructuralmente deficientes, esto debido al daño por corrosión inducido por cloruros (Higgins y Farrow, 2006). Se calcula un costo de 300,000 millones de dólares por fallas en la infraestructura, así mismo, se estima que de esa cantidad es posible evitar pérdidas por alrededor de $\mathbf{1 0 0 , 0 0 0}$ millones de dólares tomando medidas de prevención contra la corrosión (Del Valle Moreno et al., 2001). Actualmente, en México se ha detectado que más del $\mathbf{9 0} \%$ de las industrias presentan deterioros por corrosión, por ejemplo en Yucatán los costos por corrosión rebasan el $8 \%$ del Producto Interno Bruto (PIB) estatal (Hernández y Mendoza, 2006).

Los principales agentes agresivos son los cloruros en regiones marinas y la carbonatación en zonas rurales e industriales. La combinación de los agentes agresivos acelera el proceso de degradación de las estructuras de concreto reforzado; pero la resistencia de éstas dependerá tanto de la resistencia del concreto como de la resistencia del refuerzo, cualquiera de los dos que se deteriore, comprometerá la estructura como un todo. parking structures and highways, whose main characteristic is their exposure to the environment. The same occurs for structures exposed to marine environment and chemical substances in industrial factories. Due to this fact, corrosion of steel-concrete systems is a phenomenon drawing the attention of several researchers worlwide, since reinforced concrete is the most used construction system (Park and Paulay, 1990). Corrosion of reinforced steel integrally represents a durability problem that affects steel reinforcement structures to a great extent. Thus, it becomes one of the damages that cause higher costs for maintenance and operation in several constructions sites using such material (Helene and Pereira, 2003).

In 1990, an international research was developed on the economical impact derived from steel reinforced structures corrosion. The result was that between 2 and $5 \%$ of the Gross National Product (GNP), in each country, is spent to solve corrosion problems; however between 15 and $25 \%$ could have been avoided if available technology had been applied to stop it. The United Kingdom, a developed country, spends $40 \%$ of construction budget to maintenance and repair which represents $4 \%$ of its Net Domestic Product (Hernández and Mendoza, 2006). On the other hand, in The United States there are approximately 235,000 bridges, constructed with reinforced concrete, which are still in service but 21.000 of them have a defective structure because of corrosion by chloride attack (Higgins y Farrow, 2006). A total cost of 300,000 million dollars is calculated for infrastructure failure, while it is estimated that losses over 100,000 million dollars from such total amount can be avoided by taking preventive measures against corrosion (Del Valle Moreno et al, 2001). Nowadays, in Mexico it has been discovered that more than $90 \%$ of industries present corrosion damages, for example in Yucatan corrosion costs exceed $8 \%$ of Net Domestic Product (Hernández and Mendoza, 2006).

The most aggressive agents are chlorides in marine areas and carbonatation in rural and industrial areas. The combination of such aggressive agents, accelerate corrosion process of reinforced concrete structures. However their resistance will depend as much on the concrete strength as well as on reinforcement strength. If any one of them is corroded, the structure will be involved as a whole. 
Sin embargo, ni la alta alcalinidad o la baja permeabilidad del recubrimiento pueden garantizar que el acero de refuerzo pueda resistir a la corrosión indefinidamente, especialmente en ambientes marinos (Austin et al., 2004). Por lo general, la acción de éstos agentes agresivos propicia que el proceso de corrosión se inicie en el refuerzo transversal (estribos), cuyo acero es el más próximo a la superficie del concreto. Esto afecta la resistencia a cortante por tensión diagonal de la estructura, la cual se requiere para soportar concentraciones altas de esfuerzos de tensión cerca de los apoyos. Usualmente el cortante es resistido por los estribos, y un deterioro importante en su resistencia podría ocasionar una falla frágil y repentina. Esto contrasta con la naturaleza de la falla a flexión la cual se inicia con una fluencia gradual en el acero a tensión, simultáneamente se presenta un agrietamiento del concreto y grandes deformaciones que advierten sobre el problema y dan la oportunidad de tomar decisiones correctivas (Nilson, 1999).

Yoon et al. (2000), investigaron la influencia del ancho de grieta en el proceso de corrosión usando diferentes proporciones de mezcla y encontraron que cuando las grietas permanecen relativamente pequeñas ( $<1.0 \mathrm{~mm})$, tienen poco impacto en el proceso de corrosión. Por otro lado, en grietas mayores (> $1.0 \mathrm{~mm}$ ) se incrementa la velocidad de corrosión, lo cual reduce el funcionamiento total de la estructura (Yoon et al., 2000). Por lo tanto, es importante tomar en cuenta el ancho de grieta en el diseño por durabilidad de estructuras de concreto reforzado. En otra investigación (Vidal et al., 2007) estudiaron el comportamiento corrosivo y estructural en vigas de concreto reforzado expuestas a un ambiente de cloruros durante 17 años y se observó que después de la primera aplicación de carga a los 28 días de edad, el ancho de las grietas fue superior a $1.0 \mathrm{~mm}$. También se encontró, que la penetración total de cloruros en zonas de tensión y de compresión fue de $16 \mathbf{~ m m}$ de espesor; pero después de 5 años el contenido de cloruros excedió las normas establecidas por el RILEM y el ACI.

En otro estudio (Aveldaño et al., 2003), se analizaron los efectos producidos por la corrosión en el refuerzo de vigas de concreto sometidas a esfuerzos de tensión; esto con la aplicación de corrientes de 10 y 100 $\mu \mathrm{A} / \mathrm{cm}^{2}$ en un medio con cloruros $(0.3 \%)$. Se encontró que en vigas de concreto reforzado se produjo rápidamente la aparición de las primeras grietas, pero se mantuvo con un bajo crecimiento. En cambio, se incrementaron las áreas de agrietamiento rápidamente en el caso de vigas bajo carga, manifestando grietas de espesores de $0.30 \mathrm{~mm}$. Otra investigación (Yoon et al.,
Nevertheless, neither high alkalinity nor low permeability of concrete might guarantee to avoid steel reinforcement corrosion indefinitely, especially in marine environments (Austin et al., 2004). Generally, the action of such aggressive agents favors the beginning of corrosion process in the cross sectional reinforcement (stirrups), which steel is next to concrete surface. It affects the shear strength due to diagonal tensile stress in the structure, which is expected to support high concentration of tensile strength next to bearings. Usually, shear strength is provided by stirrups and a considerable loss of strength may cause a brittle and sudden failure. This differs from the nature of flexure failure, which begins with a gradual steel deformation due to tensile stress and cracks arising simultaneously as large distortions that alert the situation and give the chance to make corrective decisions (Nilson, 1999).

Yoon et al. (2000), studied cracks width influence in corrosion process by using different mixtures ratios and found that relatively small cracks $(<\mathbf{1 . 0} \mathbf{~ m m})$ have a minor impact in the corrosion process. On the other hand, larger cracks (>1.0 mm) increase corrosion speed, which reduces the proper workability of the total structure (Yoon et al., 2000). Therefore, cracking width must be taken into consideration at durability design of reinforced concrete structures. In other research (Vidal et al., 2007) studied corrosive and structural behavior on reinforced concrete beams exposed to chloride environment during 17 years; and they observed that after the first load, at 28 days of age, the cracking width was superior to $1.0 \mathrm{~mm}$. They also found that total penetration of chloride in tensile and compression areas was $16 \mathrm{~mm}$ in depth, but after 5 years the content of chloride exceeded regulations established by RILEM and ACI.

Other research (Aveldaño et al., 2003) studied the effects caused by corrosion on the reinforcement in concrete beams exposed to tensile stress, which were conducted by applying 10 y $100 \mu \mathrm{A} / \mathrm{cm} 2$ current to a chloride environment $(0.3 \%)$. They found that reinforced concrete beams rapidly produced the first cracking failures; but those kept at a low growing rate. However, the cracking areas increased rapidly in the case of loaded beams, producing 0.30-mm wide crack. Other research (Yoon et al, 
2000), estudió la interacción entre carga, corrosión y serviciabilidad en estructuras de concreto reforzado, encontrando que a un nivel alto de carga da lugar generalmente a una reducción en la iniciación del proceso de corrosión, a una velocidad de corrosión alta y a una pérdida de la capacidad de carga, debido a la falla por adherencia entre acero-concreto. Recientemente TorresAcosta et al. (2007) investigaron la relación entre el deterioro por corrosión de pequeñas vigas de concreto ( $1.50 \mathrm{~m}$ de longitud) simplemente apoyadas y la capacidad de carga a flexión basado en una metodología de corrosión acelerada (aplicación de una corriente de $80 \mu \mathrm{A} / \mathrm{cm} 2$ ). Se observó que en un ambiente seco las grietas se desarrollan rápidamente en comparación a un ambiente húmedo. Sus resultados indicaron que para una relación entre penetración de corrosión y el radio inicial de la varilla $\left(X_{\mathrm{AVER}} / r_{0}\right)$ de 0.06 y 0.1 con corrosión uniforme en un ambiente húmedo, la capacidad de carga residual disminuye hasta un $30 \%$ y $\mathbf{4 0} \%$ respectivamente, del mismo modo, si la corrosión es localizada disminuye hasta un $60 \%$ con una relación $X_{\mathrm{AVER}} / r_{0}$ de 0.1 .

Sin embargo, se ha encontrado poca información en la literatura sobre estudios del problema de deterioro en el acero transversal en condiciones de escala natural de elementos estructurales, pero la corrosión es un factor importante en la durabilidad de vigas de concreto reforzado, debido a que, modifica las propiedades mecánicas de estas como la capacidad a cortante por tensión diagonal. De tal manera, la presente investigación pretende correlacionar los parámetros de corrosión y la resistencia a cortante por tensión diagonal que permita predecir una relación confiable entre el comportamiento estructural y la durabilidad de vigas de concreto reforzado.

\section{Procedimiento experimental}

\subsection{Materiales}

Se utilizó concreto premezclado f'c $=20 \mathrm{MPa}$, con un tamaño máximo nominal de agregado de $19 \mathrm{~mm}$ y una consistencia del concreto de $85 \mathrm{~mm}$, que fue medida mediante la norma ASTM C 143-00. El acero de refuerzo longitudinal, fueron varillas No. 5 (16 $\mathrm{mm}$ de diámetro) y varillas para el refuerzo transversal de No. 2.5 (8 mm de diámetro) con un $\mathrm{f}_{\mathrm{y}}=420 \mathrm{MPa}$, se preparó la superficie del refuerzo mediante una limpieza manual con un cepillo de cerdas metálicas, para retirar el óxido superficial. Las varillas longitudinales se recubrieron con una pintura epóxica a base de resinas para evitar su corrosión. Para evitar la formación de pilas galvánicas,
2000) studied the interaction between load, corrosion and service conditions in reinforced concrete structures, finding that a high level of load generally leads to a shortenning of the beginning of corrosion process, to a high corrosion speed and to a loss of loading capacity, because of bonding failures between steel-concrete. Recently, Torres-Acosta et al. (2007) studied the relation between failure because of corrosion in small simply supported concrete beams $(1.50 \mathrm{~m}$ long) and the flexure load capacity based on an accelerated corrosion method (applying $80 \mu \mu \mathrm{A} / \mathrm{cm} 2$ current). It was observed that dry environment favors cracking faster than dampening environments. Results concluded that a ratio between penetration and initial reinforcement radius $\left(X_{\mathrm{AVER}} / r_{0}\right)$ of 0.06 and 0.1 - steadily corroded in a wet environment the residual load decreases up to $30 \%$ and $40 \%$ respectively. In the same way, if corrosion is located, it will decrease up to $60 \%$ at a ratio $X_{\mathrm{AVER}} / r_{0}$ of 0.1 .

However, there is little literature information about experimental studies on damage problems in cross sectional steel, under a natural conditions scale for structural elements, but corrosion is still a major factor affecting durability of reinforced concrete beams, since corrosion modifies mechanical properties, such as shear strength due to diagonal tensile stress. In this way, the present study intends to correlate corrosion parameters and shear strength due to diagonal tensile strength, in order to foresee a reliable relation between the structure behavior and reinforced concrete beams durability.

\section{Experimental method}

\subsection{Materials}

Ready mixed concrete $f^{\prime} \mathrm{c}=20 \mathrm{MPa}$ was employed, with a maximum nominal aggregate size of $19 \mathrm{~mm}$; and concrete slump of $85 \mathrm{~mm}$, measured in accordance with ASTM C 143-00. 16-mm diameter reinforcement bars were employed (\#5) for flexure reinforcement steel and 8-mm diameter bars $(\# 2.5)$ for shear reinforcement, with $\mathrm{f}_{\mathrm{y}}=420 \mathrm{MPa}$, the reinforcement surface was manually cleaned by using a metal brush, to remove superficial corrosion products. Longitudinal bars were covered with an epoxy resin coating to avoid corrosion. So as to avoid the formation of galvanic piles 
en los puntos de contacto entre el acero longitudinal y transversal, se procedió a recubrir estos puntos con cinta de aislamiento. De igual forma, se sustituyó el alambre recocido por cintillas de nylon, esto para sujetar el refuerzo transversal con el longitudinal.

\subsection{Fabricación de especímenes}

Se fabricaron 16 vigas de concreto reforzado de 2000 x 200 x 350 mm, con separaciones de 150 y 200 mm entre el refuerzo transversal (ver Figura 1), y se curaron los primeros 7 días con lámina de agua dentro de la cimbra, se desmoldaron y posteriormente se le colocó una membrana de curado hasta los 28 días de edad. Para el control de la calidad del concreto se fabricaron nueve cilindros de concreto de 150 x $300 \mathrm{~mm}$ para determinar su resistencia a la compresión a los 7, 14 y 28 días de edad; y cilindros de 100 × $200 \mathrm{~mm}$ los cuales fueron utilizados para obtener la penetración de iones cloruros a diferentes tiempos durante la inducción del deterioro. on the contact points between the longitudinal and shear steel, those points were covered with an insulation tape. Besides, wire was replaced by nylon strips in order to hold flexure and shear reinforcements.

\subsection{Specimens Construction}

162000 x 200 x $350 \mathrm{~mm}$ reinforced concrete beams were fabricared, each having a spacing distance of 150 and $200 \mathrm{~mm}$ between the longitudinal reinforcement (see Figure 1). Beams were cured for 7 days with a water sheet inside forms; then beams were unmolded and covered with a curing compound up to 28 days of age. For concrete quality control, nine $\mathbf{1 5 0}$ x $300 \mathrm{~mm}$ concrete cylinders were cast ans tested to estimate the compression strength at 7,14 and 28 days of age. $100 \times 200$ cylinders of were also orepared to obtain results on chloride ions penetration at different ages, during damage induction.

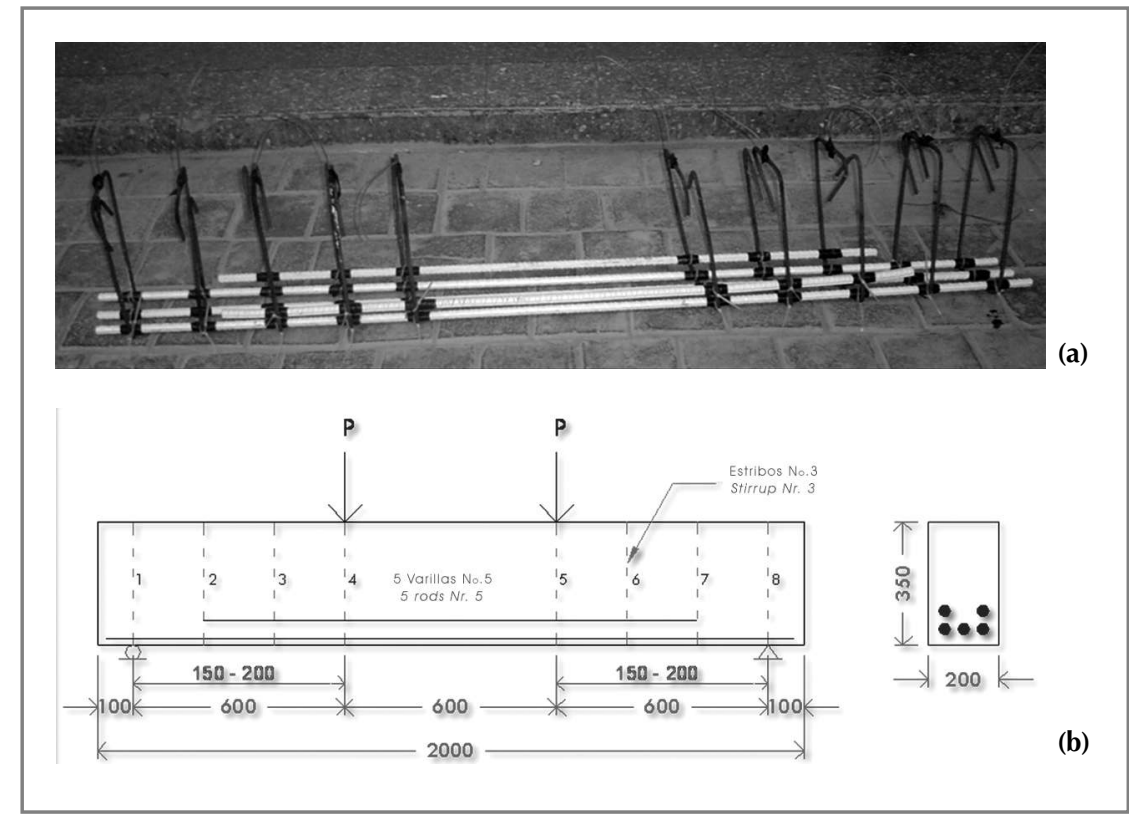

Figura 1. a) Armado del refuerzo b) Esquema del armado del refuerzo, acotaciones en $\mathbf{m m}$.

Figure 1. a) Reinforcement (actual). b) Reinforcement (scheme), distances in $\mathrm{mm}$.

\subsection{Inducción del deterioro}

Antes de iniciar el proceso de inducción de corrosión acelerada se pintó la cara superior e inferior de las vigas con impermeabilizante, para garantizar solamente la corrosión en los estribos. También, se retiró la membrana de curado de las caras laterales con cepillo de cerdas metálicas. Se tomó la lectura inicial de velocidad y potencial de corrosión de cada estribo de las 16 vigas como lecturas base para el desarrollo experimental.

\subsection{Damage induction}

Before beginning the accelerate corrosion induction process the upper and lower beam faces were covered with waterproofing painting, so as to guarantee corrosion on stirrups only. The curing membrane was removed from side faces by using a metallic bristle brush. Initial corrosion rate and corrosion potential in each stirrup of 16 beams were measured and taken as basis for the experimental test. 
El proceso de inducción de corrosión acelerada en el refuerzo transversal de las vigas, fue realizado mediante ciclos de tres días de humectación utilizando una solución de $3.5 \%$ de $\mathrm{NaCl}$ y cuatro días de secado al aire libre. La humectación de las vigas se lleva acabo por medio de esponjas de poliuretano, las cuales están sujetadas en la zona de los estribos. Estas esponjas son humectadas cada 3 horas con la solución de $\mathrm{NaCl}$ durante el ciclo de humectación, y para evitar la evaporación de la solución las vigas se cubren con plástico (Ver Figura
The accelerate corrosion induction process for shear reinforcement, was conducted through three days dampening cycles using a $3.5 \% \mathrm{NaCl}$ solution and four days for drying in the open air. Dampening the beams is done by employing polyurethane foams which are fixed at the stirrups zone. These foams are dampened with $\mathrm{NaCl}$ solution every three hours during the dampening cycle, in order to avoid the solution evaporation; beams are covered with a plastic film. (Ref. Figure 2). 2).

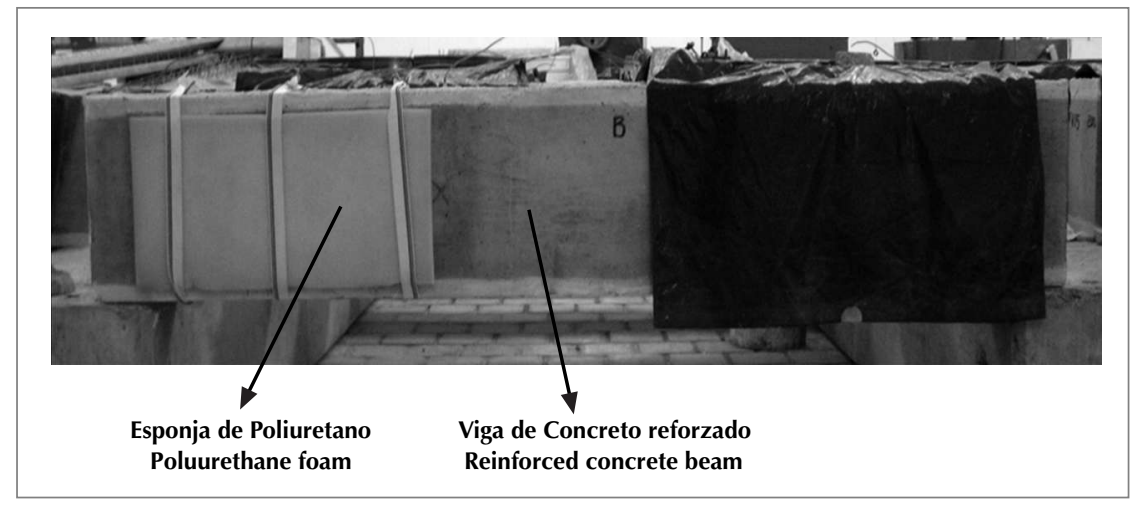

Figura 2. Inducción del deterioro de las vigas

Figure 2. Beams damage induction

\subsection{Evaluación y seguimiento del deterioro}

El monitoreo de parámetros electroquímicos se lleva a cabo mediante el Corrosion Rate Meter LG - ECM06, James NDT Instruments (GECOR6) y el Galva Pulse GP 5000 de acuerdo a la norma ASTM C 876. Los niveles de corrosión incipiente (Ecorr >-350 mV, despasivación del acero), moderada (Aparición y propagación de agrietamiento, ancho de grieta $<0.1 \mathrm{~mm}$ ) y severa (propagación de agrietamiento, ancho de grieta $>0.1$ $\mathbf{m m}$, desprendimiento, manchas), se definieron con respecto al criterio del RILEM (Andrade y Alonso, 2004) que determina estos niveles con la clasificación de los resultados de velocidad y potencial de corrosión y mediante una inspección visual de la superficie de las vigas, esto de acuerdo a las recomendaciones de la bibliografía consultada.

\subsection{Ensaye de las vigas}

Una vez alcanzado los niveles de corrosión previamente definidos, las vigas serán ensayadas a flexión, lo que producirá altos niveles de esfuerzos por tensión diagonal cerca de los apoyos. Las vigas de control (sin corrosión) fueron ensayadas previamente al proceso de corrosión,

\subsection{Damage evaluation and control}

Monitoring of electrochemical parameters is conducted by employing the Corrosion Rate Meter LG - ECM-06, James NDT Instruments (GECOR6) and the Galva Pulse GP 5000 in accordance with ASTM C 876 regulation. The corrosion levels are incipient (Ecorr >$350 \mathrm{mV}$, steel depassivation), moderate (cracking appearance and spreading, cracking width $<0.1 \mathrm{~mm}$ ) and severe (cracking spreading, cracking width $>0.1$ mm, decoupling, spots), which were defined according to RILEM (Andrade and Alonso, 2004), that determines these levels with classification results on speed and potential corrosion by means of visual inspection on the beam surface, as per recommendations in the consulted bibliography.

\subsection{Beams Tests}

When previously defined corrosion levels are achieved, beams will be placed under flexure strength, which will produce high levels of diagonal tensile stress near the bearings. Control beams (not corroded) were tested prior to corrosion process, 
aplicando cargas concentradas a $600 \mathrm{~mm}$ de los apoyos (Figura 1). Para tener un control del avance de agrietamiento de las vigas se aplicó carga en etapas de $5 \mathrm{kN}$. La resistencia teórica a cortante para las vigas, se obtuvo de acuerdo con las recomendaciones del código del Instituto Americano del Concreto (ACI 318-08).

En la Figura 3 se muestra un diagrama experimental, en donde se puede apreciar el proceso por el cual se someterán las $\mathbf{1 6}$ vigas de concreto reforzado. applying concentrate loads at $600 \mathrm{~mm}$ from bearings (Figure 1). In order to monitor the beams cracking progress, a load of $5 \mathrm{kN}$ was applied in different stages. The beams theoretical shear strength was obtained according to recommendations in the Code of American Concrete Institute (ACI 318-08).

Figure 3 shows an experimental diagram, indicating the experimental process underwent by the 16 reinforced concrete beams.

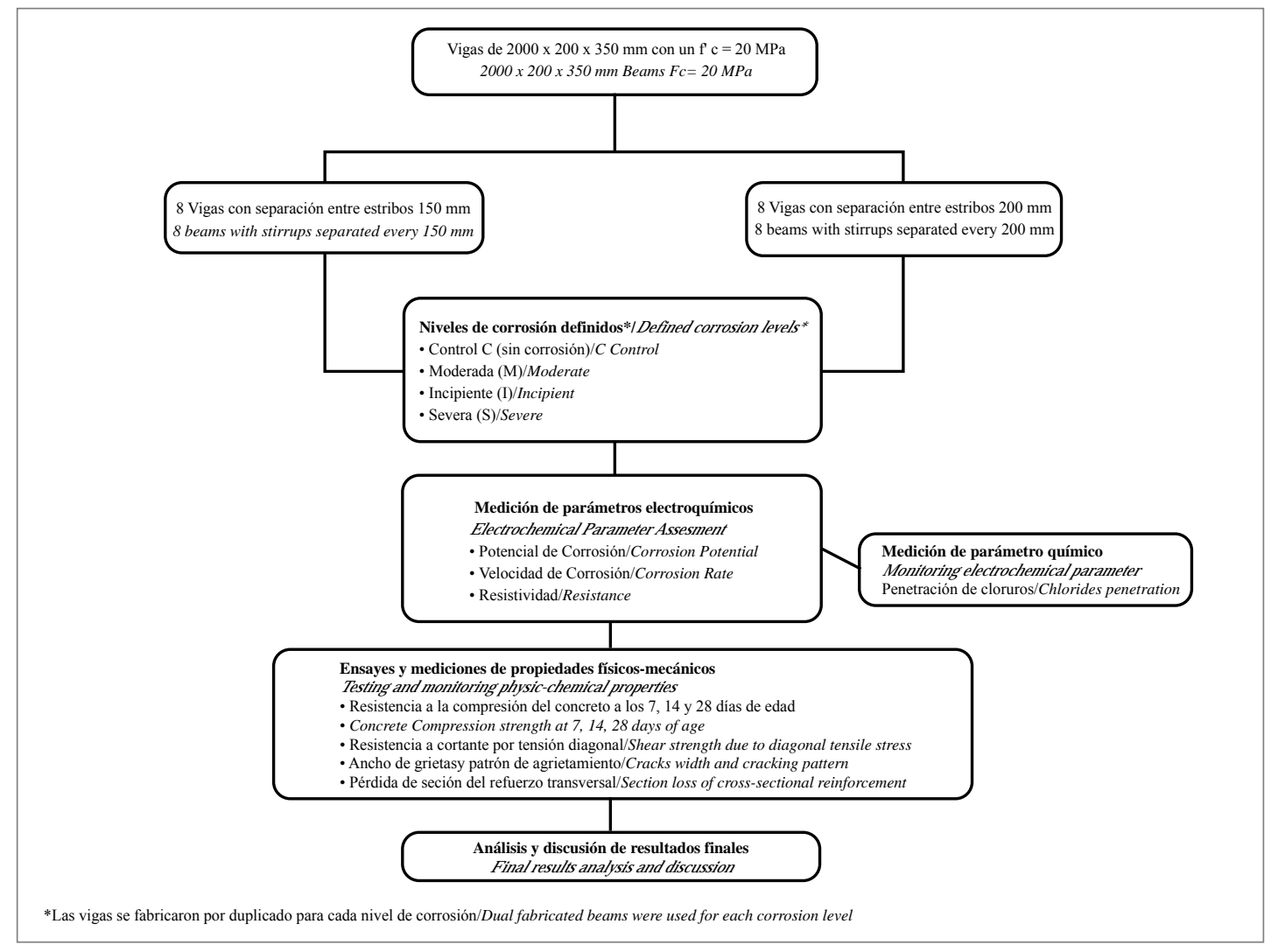

Figura 3. Diagrama experimental

Figure 3. Experimental diagram

\section{Resultados preliminares}

De los cilindros de concreto de 150 x $300 \mathrm{~mm}$ se obtuvo valores de la resistencia a la compresión de 16, 19 y $21 \mathrm{MPa}$ a 7, 14 y 28 días de edad respectivamente, esto mediante un promedio de tres ensayes (como se especifica en la norma ASTM C 39/C39M-03).

De los cilindros de 100 × 200 mm los cuales se sometieron a ciclos de humedecimiento y secado, se obtuvo una concentración de cloruros acuasolubles a una profundidad de $10 \mathrm{~mm}$ de $\mathbf{0 . 4 3} \%$ ppc (por peso de cemento), y para una profundidad de $20 \mathrm{~mm}$ no fue determinada debido a la sensibilidad del equipo,

\section{Preliminary results}

From $150 \times 300 \mathrm{~mm}$ concrete cylinders, the following compression strengths were obtained: 16, 19 and $21 \mathrm{MPa}$ at 7, 14 and 28 days of age respectively, this was calculated by averaging three specimens at each age (as specified by ASTM C 39/C39M-03 regulation). From Cylinders of $100 \times 200$ mm, which were exposed under dampening and drying cycles, a concentration of water-soluble chlorides at $10 \mathrm{~mm}$ depth of $0.43 \%$ pcw (per concrete weight) was obtained; at $20 \mathrm{~mm}$ depth it was not possible to determine any concentration of chlorides, 
por lo tanto, se obtuvo valores menores a $0.24 \%$ ppc. El valor a una profundidad de $10 \mathrm{~mm}$ esta por encima del límite permitido por el ACI $318-08$ que es $0.15 \%$ en ambiente de $\mathrm{Cl}$, esto nos dice que se verán resultados del proceso de corrosión a edades tempranas.

Con la concentración de cloruros acuasolubles previamente mencionada y el recubrimiento en las vigas $(\approx 2 \mathrm{~cm}$ ), se obtuvo el tiempo teórico en el cual los cloruros llegarán a despasivar al acero de refuerzo, este fue de 28 días aproximadamente, pero este valor puede variar debido a la multitud de parámetros que influyen (porosidad del concreto, tipo de cemento, contenido de humedad del concreto, etc.). Esto se observa en nuestras vigas ya que, tienen 98 días de exposición al proceso de deterioro y solo el $20 \%$ de los estribos están despasivados.

En la Figura 4 se observa los potenciales de corrosión a 98 días de exposición al deterioro, y de acuerdo a la norma ASTM C 876 tres de los estribos de las vigas 4, 7 y 8 se sitúan en el estado de probabilidad de corrosión alta con valores inferiores a $\mathbf{- 3 5 0} \mathrm{mV}$, por lo tanto, estas vigas están en un nivel de corrosión incipiente. Mientras que los estribos de las vigas 3, 5 y 6 presentan valores superiores a $\mathbf{- 3 5 0} \mathrm{mV}$, por lo que, se sitúan en un estado de probabilidad de corrosión baja. because values obtained were below $0.24 \%$ pcw which is under the equipment sensitivity the value at $10 \mathrm{~mm}$ depth is over the limit permitted by the $\mathrm{ACI}$ 318-08 that is $0.15 \%$ for a $\mathrm{Cl}$ environment. Above indicates that corrosion process results will appear at early ages.

From the water-soluble chloride concentration previously mentioned and beam covering $\approx 2 \mathrm{~cm}$ ), the theoretical time in which chlorides would depassivate the reinforcement steel was calculated in 28 days approximately, however, this value might vary due to multiple parameters involved (concrete porosity, type of cement, concrete moisture, etc.). This can be observed in the test beams which have been exposed to damage for 98 days and only $20 \%$ of stirrups are depassivated.

Figure 4 shows the potential corrosion at 98 days from damage exposure, as per ASTM C 876 regulation, three stirrups out of beams 4,7 and 8 are likely to be under corrosion with values under $-350 \mathrm{mV}$, therefore, these beams are at an incipient corrosion level. Meanwhile, stirrups of beams 3, 5 and 6 yield values above $-350 \mathrm{mV}$, so they are at a low corrosion probability condition.
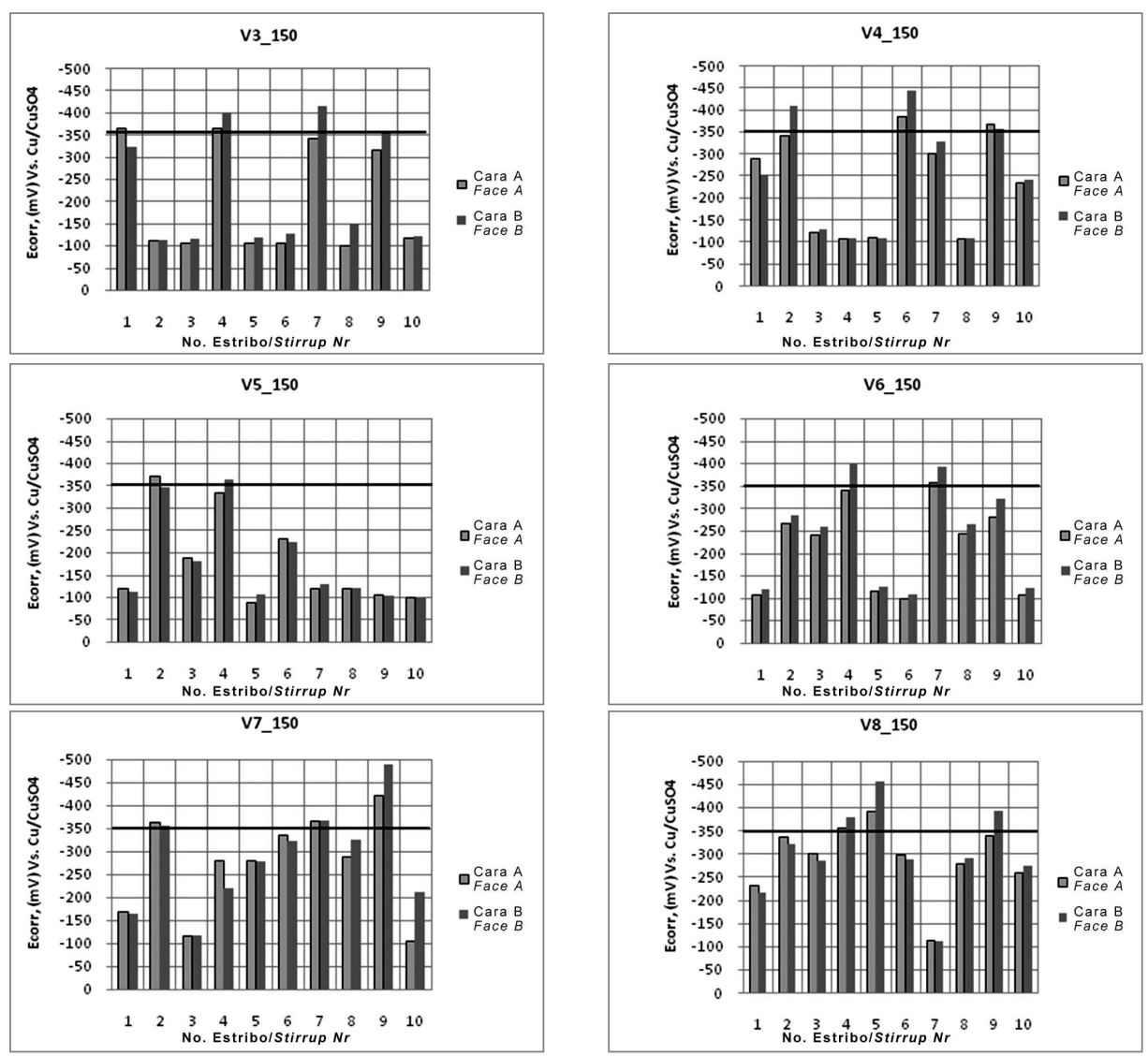

Figura 4. Potencial de corrosión del estribo medido en ambas caras de la viga, con separación de $150 \mathrm{~mm}$ entre estribos Figure 4. Stirrup Corrosion Potential measured on both beam faces, at a spacing distance of $150 \mathbf{~ m m}$ between stirrups *El No. de estribo está indicado en la Figura $1 . \quad$ *The stirrup number is indicated in Figure 1. 
En la Figura 5 se observa los potenciales de corrosión a 98 días de exposición al proceso de deterioro, en donde se aprecia que los estribos 4, 5 y 6 de las vigas 11 y 14 se sitúan en el estado de probabilidad de corrosión alta con valores inferiores a $\mathbf{- 3 5 0} \mathbf{~ m V}$, mientras que la mayoría de los estribos de las vigas 13, 15 y 16 se sitúan en un estado de probabilidad de corrosión baja con valores superiores a $\mathbf{- 3 5 0} \mathrm{mV}$, e incluso con valores superiores a -200 $\mathbf{m V}$. Por otro lado en la viga 12 los estribos 1, 2, 3, 6, 7 y 8 presentan valores entre -200 y $-350 \mathrm{mV}$ y aunque esto sitúa al acero de refuerzo en una probabilidad de corrosión intermedia, se puede ver que existe una tendencia a incrementar el potencial.
In Figure 5 the corrosion potentials can be observed at 98 days of exposure to damage process, where it can be seen that stirrups 4,5 and 6 of beams 11 and 14 are at a high corrosion condition with values under $-350 \mathrm{mV}$, while most stirrups in Beams 13, 15 and 16 are at a low corrosion condition with values above $350 \mathrm{mV}$, and even above $\mathbf{- 2 0 0} \mathbf{~} \mathrm{V}$. On the other hand, in beam 12 the stirrups 1, 2, 3, 6, 7 and 8 present values between -200 and $-350 \mathrm{mV}$ and even though it places reinforcement concrete at an intermediate corrosion probability condition, there is a trend to increase the potential.
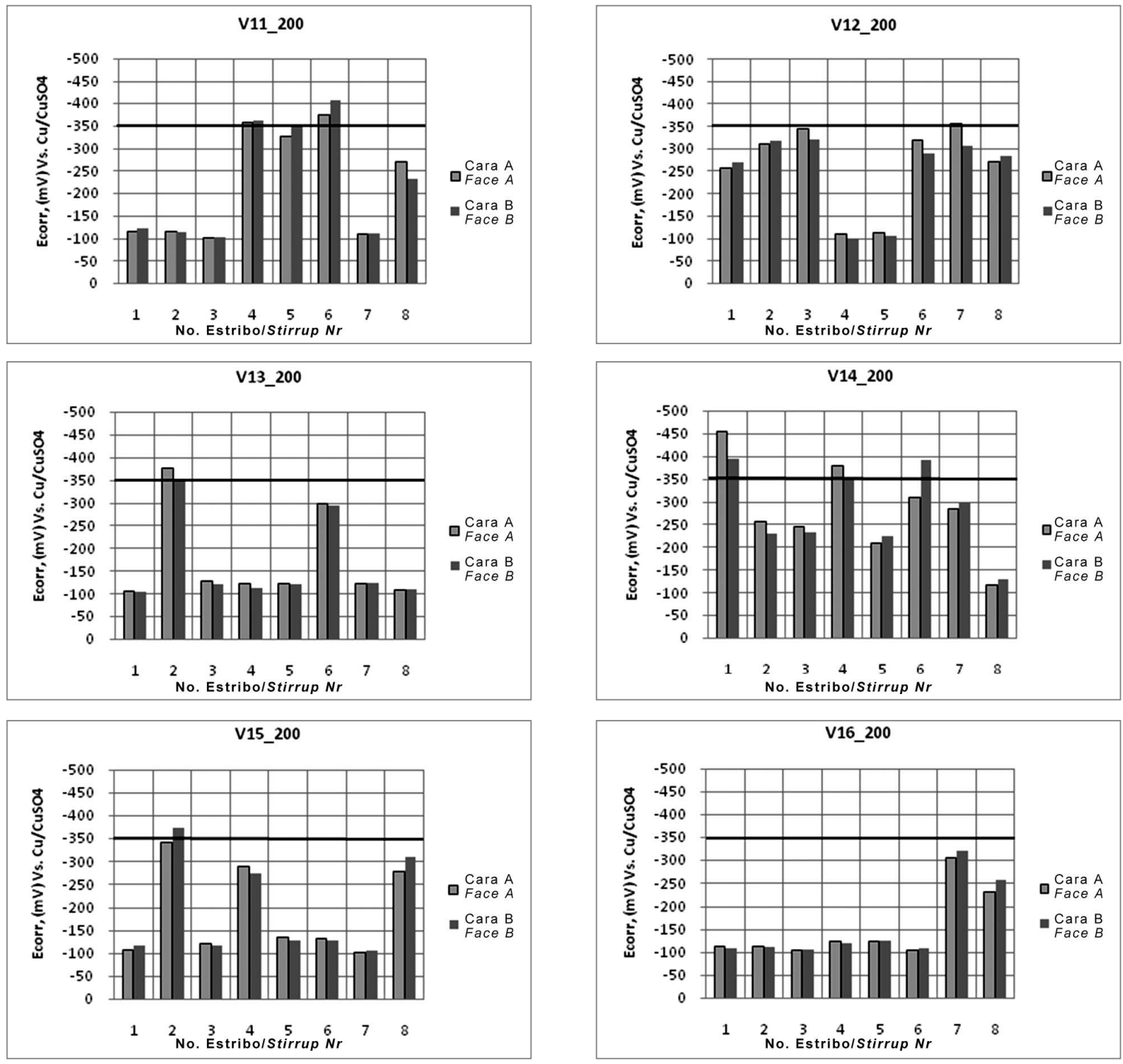

Figura 5. Potencial de corrosión del estribo medido en ambas caras de la viga, con separación de 200 mm entre estribos Figure 5. Stirrup Corrosion Potential measured on both beam faces, at a spacing distance of $200 \mathbf{~ m m}$ between stirrups.

*EI No. de estribo está indicado en la Figura 1

*The stirrup number is indicated in Figure 1. 
En la Figura 6 se aprecian los resultados del ensaye mecánico de las vigas de control, en donde se puede observar que la resistencia ultima a cortante para las vigas con estribos separados a cada $150 \mathrm{~mm}$ fue mayor en un $25 \%$ a las vigas con estribos separados a $200 \mathrm{~mm}$. Se muestra la resistencia teórica a cortante, encontrándose que es similar a la resistencia obtenida en el ensaye. También se observa que la separación de los estribos no influyo en la ductilidad de las vigas ensayadas.
Figure 6 shows the results from mechanical test on control beams, where it can be observed that the ultimate shear strength of beams having stirrups separated every $150 \mathrm{~mm}$ was $25 \%$ higher than beams separated every $200 \mathrm{~mm}$. The theoretical shear strength is proved to be similar to the shear strength obtained from the test. It is also concluded that stirrups spacing distance did not influence ductility of tested beams.
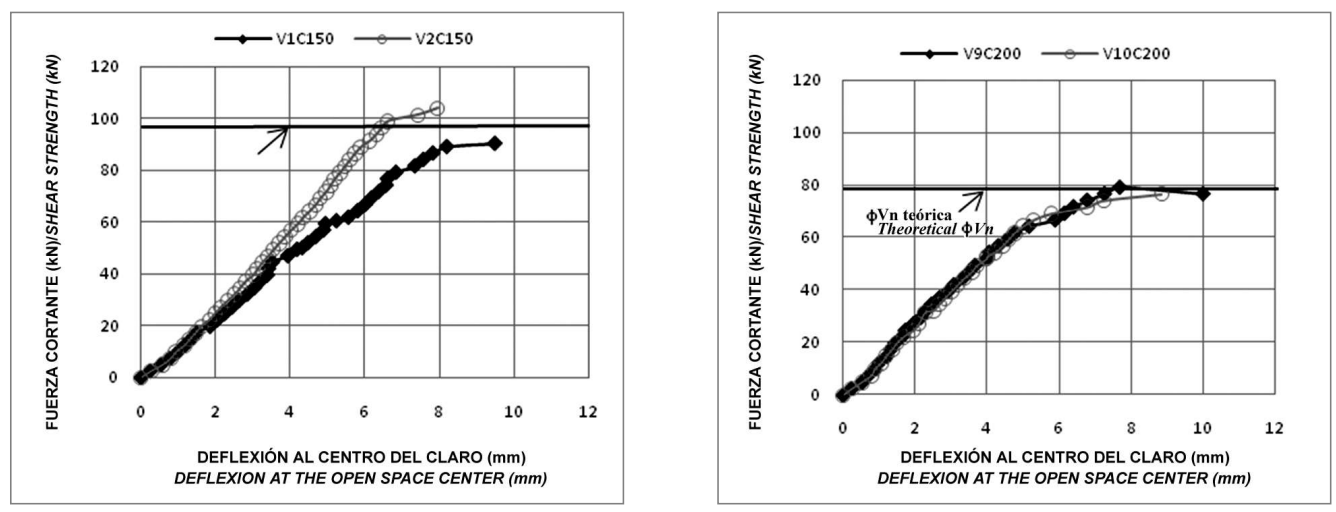

Figura 6. Deflexiones en el acero transversal

Figure 6. Deflections for shear reinforcement steel

La falla de las vigas de control fue a cortante por tensión diagonal con un patrón de agrietamiento mostrado en la Figura 7. En donde se puede observar la aportación de los estribos separados a $150 \mathrm{~mm}$ que generan un mayor agrietamiento en la zona de tensión ocasionado por cargas mayores y cercanas a la que provocaron la falla por cortante
Control beams failure was caused by shear strength due to diagonal tensile stress. The cracking pattern is shown in Figure 7, where we can notice the contribution of fixing stirrups every $150 \mathrm{~mm}$ that produced major cracking in the tensile zone, due to heavier loads which are similar to the ones causing the shear strength failure.

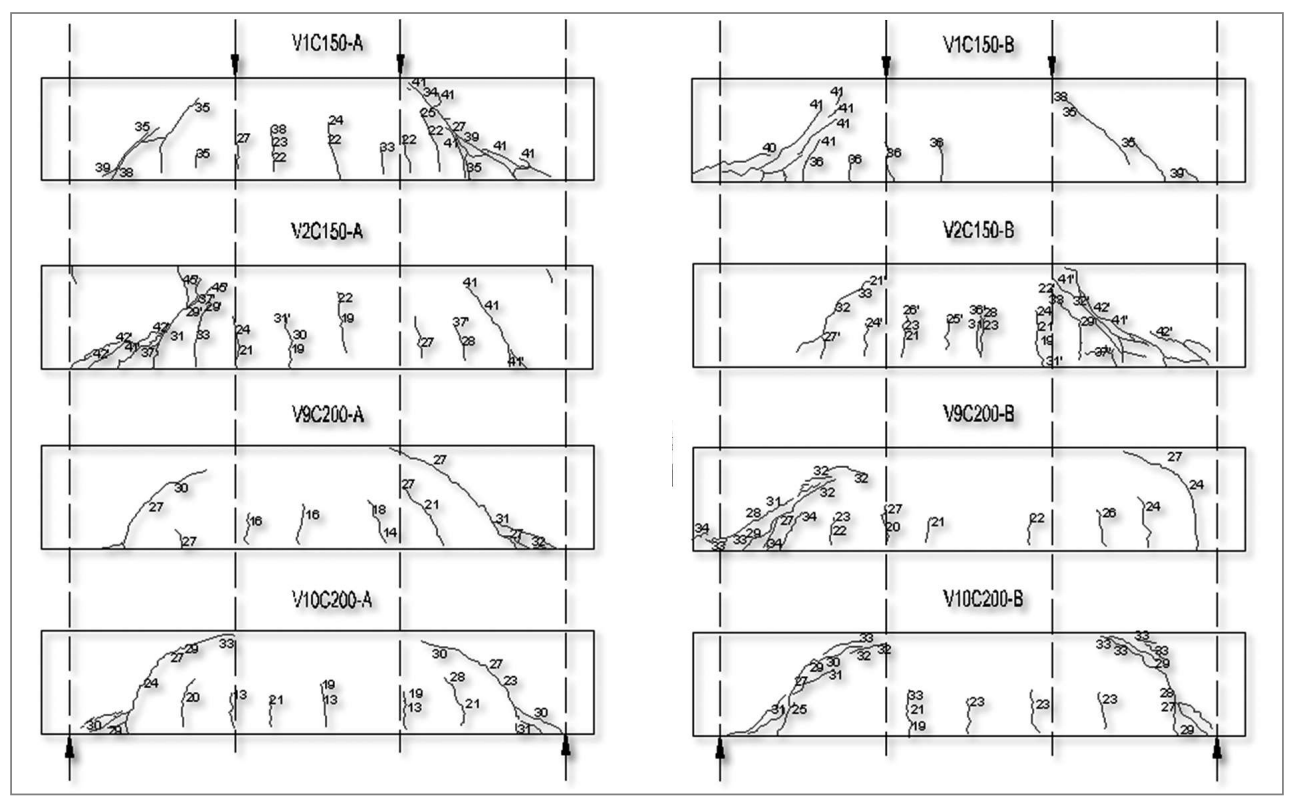

Figura 7. Patron de agrietamiento de las vigas de control. Los valores sobre las grietas representan el número de ciclo de carga (la carga total promedio por ciclo fue de $5 \mathrm{kN}$ )

Figure 7. Cracking Pattern for Control Beams. Values above cracks represent the load cycle number (total average load per cycle was $5 \mathrm{kN}$ ) 


\section{Discusión y comentarios finales}

Los resultados obtenidos en los potenciales de corrosión variaron de acuerdo a la separación entre estribos, ya que en las vigas con separaciones de 150 mm se pudo apreciar que presenta una tendencia a superar en menos tiempo potenciales menores a - $\mathbf{3 5 0} \mathbf{~ m V}$. Mientras que las vigas con separaciones entre estribos de $200 \mathrm{~mm}$, presentan valores superiores a $\mathbf{- 3 5 0} \mathrm{mV}$, esto en la mayoría de los estribos. Esto nos dice que las vigas con separaciones de $150 \mathrm{~mm}$ son las más próximas a alcanzar un nivel de corrosión incipiente (despasivación del acero de refuerzo), en comparación con las de separación de $200 \mathrm{~mm}$.

En las vigas de control ensayadas se obtuvo que la resistencia cortante última es similar a la resistencia teórica según $\mathrm{ACl}-318-08$. Además, la vigas con mayor refuerzo transversal (separación de $150 \mathrm{~mm}$ ) presentaron mayor ductilidad lo cual era de esperarse, sin embargo, también proporcionaron un múltiple agrietamiento en la zona de cortante y tensión.

Con los resultados obtenidos hasta el momento se vislumbra la verificación de la pérdida de capacidad a cortante por tensión diagonal de vigas de concreto en función del deterioro por corrosión inducido en los estribos a través de ciclos de mojado y secado con $\mathrm{Cl}^{-}$.

\section{Agradecimientos}

Los trabajos descritos en este artículo fueron desarrollados en el Instituto de Ingeniería Civil de la FICUANL. Los autores expresan su más profundo agradecimiento al PAICYT y SEP por los apoyos financieros otorgados a los proyectos CA-1499-07, CA-1477-07 PROMEP/103.5/07/0293 respectivamente. A la Ing. Mercedes Balancán Zapata quién labora en el CINVESTAVIPN Unidad Mérida, por el apoyo brindado para el desarrollo de ésta investigación y por sus valiosas sugerencias e interés mostrado. A los estudiantes de la Facultad de Ingeniería Civil-UANL que han brindado su ayuda durante esta investigación.

\section{Discussion and final comments}

The obtained corrosion potential results varied wuth stirrups spacing, since it can be observed that beams with stirrups spacing of $150 \mathrm{~mm}$ tend to present corrosion potentials below $-350 \mathrm{mV}$ in shorter periods of time. While beams with stirrups spacing of $200 \mathrm{~mm}$, provide values above $-350 \mathrm{mV}$, in most of the stirrups. This indicates that beams with stirrups spacing of $150 \mathrm{~mm}$ are most likely to reach an incipient corrosion level (depassivation of reinforced steel), in comparison to 200 mm spacing distance ones.

The tested control beams showed that the ultimate shear strength is similar to theoretical strength as per $\mathrm{ACl}-318-08$. B. As expected, the beams which were heavily shear reinforced (spacing of $150 \mathrm{~mm}$ ), showed higher ductility capacity. However, they also showed multiple cracks in shear and tensile stressed zone.

From results obtained so far, the loss capacity for shear strength due to concrete beams diagonal tensile stress can be expected based on the corrosion damage obtained at the stirrups through chloride dampening and drying cycles.

\section{Acknowledgements}

The experimental studies described in this article were developed at Instituto de Ingeniería Civil de la FICUANL. The authors express their deepest gratitude to PAICYT and SEP for the financial support provided through CA-1499-07, CA-1477-07 PROMEP/103.5/07/0293 projects, respectively. Our special thanks to Mercedes Balancán Zapata, Eng., who works at CINVESTAV-IPN Mérida Unit, for her valuable suggestions and interest shown in our research. We express our gratitude to students at the School Civil Engineering- UANL, who provided assistance during this research. 


\section{Referencias / References}

ACI 318S-08 (2008), American Concrete Institute, Requisitos de Reglamento para Concreto Estructural, 59. Andrade C. y Alonso C., Noviembre (2004), RILEM TC 154-EMC, “Test methods for on-site corrosion rate measurement of steel reinforcement in concrete by means of the polarization resistance method", , Materials and Structures, Vol. 37, 623-643. ASTM C 876-91 (reapproved 1999), "Standard Test Method for Half-Cell Potentials of Uncoated Reinforcing Steel in Concrete". American Society for Testing and Materials, 461-466, Philadelphia.

ASTM C 143-00 (2000), "Standard Test Method for Slump of Hydraulic-Cement Concrete". American Society for Testing and Materials, 1-3, Philadelphia.

ASTM C 39/C39M-03 (2003), "Standard Test Method for Compressive Strength of Cylindrical Concrete Specimens". American Society for Testing and Materials, 21-25 Philadelphia.

Austin S.A., Lyons R. y Ing M.J. (2004), "Electrochemical Behavior of Steel-Reinforced Concrete During Accelerated Corrosion Testing", Corrosion Engineering Section, vol 60, No.2, 203-212.

Aveldaño R.R., Ortega N.F. y Bessone J.B. (2004), “Corrosión bajo tensión en hormigón armado. Efectos de la Densidad de corriente y composición del medio electrolítico", Jornadas SAM - CONAMET-AAS Simposio Materia 521-542.

Del Valle Moreno A., Pérez López T. y Martínez Madrid M. (2001), El Fenómeno de la Corrosión en Estructuras de Concreto Reforzado, Secretaria de Comunicaciones y Transportes Instituto Mexicano del Transporte (SCT), Publicación Técnica No. 182, 1-88 Sanfandila, Qro.

DURAR Red Temática XV.B Durabilidad de la Armadura, Manual de Inspección, Evaluación y Diagnóstico de Corrosión en Estructuras de Hormigón Armada (1998), CYTED Programa Iberoamericano de Ciencia y Tecnología para el Desarrollo, 2a. Edición, 37-39. Higgins Christopher y Farrow III William C., Enero-Febrero (2006), "Tests of Reinforced Concrete Beams with Corrosion-Damaged Stirrups" ACI Structural Journal, Technical Paper, 133-141.

Helene P. y Pereira F. (2003), Manual de Rehabilitación de Estructuras de Hormigón, Reparación, Refuerzo y Protección. REHABILITAR, CYTED.

Hernández-Castañeda O. y Mendoza Escobedo C. J. (2006), Durabilidad e Infraestructura: Retos e Impacto Socioeconómico, INGENIRíA Investigación y Tecnología VII 1, 57-70 Universidad Autónoma de México, Distrito Federal. México. Nilson H. (1999), Diseño de estructuras de concreto, Mc. Graw Hill, Duodécima Edición, 105-121.

Park R. y Paulay T., (1990) Estructuras de Concreto Reforzado, ED. Limusa Noriega, Nueva Edición, 288-294. Torres-Acosta A. A., Navarra-Gutiérrez S. y Terán-Guillén J. (2007), Residual flexure capacity of corroded reinforced concrete beams, Engineering Structures 29, 1145-1152.

Vidal T., Castel A., François R. (2007), “Corrosion process and structural performance of a 17 year old reinforced concrete beam stored in chloride environment", Cement and Concrete Research 37, 1551-1561.

Yoon Sanchu, Kejin Wang, W. Jason Weiss y Surendra P. Shah, Noviembre-Diciembre (2000), "Interaction between Loading, Corrosion, and Serviceability of Reinforced Concrete", ACI Materials Journal, Technical Paper, 637-644. 